\title{
POWER COEFFICIENT IN ONE POINT LIQUID LIMIT TEST FOR SOILS OF NORTHERN TURKEY AT VARIOUS TEMPERATURES
}

\author{
${ }^{1}$ Emre ÜYETÜRK, ${ }^{2}$ Nejan HUVAJ \\ ${ }^{1}$ Middle East Technical University, Department of Civil Engineering, 06800, Ankara, Turkey, \\ ${ }^{2}$ Middle East Technical University, Department of Civil Engineering, 06800, Ankara, Turkey \\ 1emreuyeturk@gmail.com, 2nejan@metu.edu.tr
}

(Geliş/Received: 20.02.2018; Kabul/Accepted in Revised Form: 17.04.2018)

\begin{abstract}
In this study, the power coefficient of one-point liquid limit equation given by ASTM 4318-17 is evaluated for weathered volcanic deposits of Northern Turkey. Total of 35 soil samples taken from depths ranging from $0.2 \mathrm{~m}$ to $4 \mathrm{~m}$ from 8 different sites in the city of Rize and one site in Trabzon, Turkey are used, and a total of 77 Atterberg limit tests are conducted. Three different sample preparation methods are used: (1) starting from in-situ moisture content without any drying, (2) drying at $60^{\circ} \mathrm{C}$ oven, (3) drying at $110^{\circ} \mathrm{C}$ oven. For liquid limit determination by one-point method, the best fitting power coefficient is evaluated for different sample preparation conditions separately, and are compared with the power coefficient suggested by ASTM D4318-17. Soils used in this study are in ML-OL to MH-OH zones in plasticity chart and the liquid limit values vary in the range of $35 \%$ to $103 \%$ (moist preparation). Liquid limits obtained by multi-point method and the ones obtained by one-point method are found to be similar to each other. It is concluded that although the power coefficient changes (in the range of 0.106 to 0.133 with an average value of 0.120 ) due to sample preparation technique, they are close to ASTM-suggested power value of 0.121 , and the differences in resulting liquid limits are negligibly small $(0-2 \%)$.
\end{abstract}

Key Words: Liquid limit, Multi point, One point

\section{Türkiye'nin Kuzeyindeki Zeminler İçin Farklı Sıcaklıklarda Tek Nokta Likit Limit Deneyindeki Üstel Katsayı}

ÖZ: Bu çalışmada ASTM D4318-17 tarafından önerilen tek nokta likit limit saptama denklemindeki üstel katsayı Türkiye'de Doğu Karadeniz bölgesinde bulunan ayrışmış volkanik zeminler için belirlenmiştir. Numuneler $0.2 \mathrm{~m}$ ila $4 \mathrm{~m}$ derinliklerden, Rize'den 8 sahadan ve Trabzon'dan 1 sahadan alınmış olup toplamda 35 adettir ve bu numunelerle 77 adet Atterberg kıvam limitleri deneyi yapılmıştır. Bu çalışmada 3 farklı numune hazırlama yöntemi kullanılmıştır. Bunlar (1) herhangi bir ısıtmaya maruz bırakılmadan doğal su muhtevasından numune hazırlama, (2) $60^{\circ} \mathrm{C}$ firında kurutulduktan sonra hazırlama ve (3) $110^{\circ} \mathrm{C}$ firında kurutulduktan sonra hazırlamadır. Tek nokta likit limit saptama denklemindeki üstel katsayı, farklı yöntemlerle hazırlanan numuneler için hesaplanmış ve bu üstel katsayı ASTM D4318-17 standardında tavsiye edilen değer ile karşılaştırılmıştır. Bu çalışmada kullanılan zeminler Plastisite abağında ML-OL ve MH-OH sınıfında olup likit limit değerleri \%35 ile \%103 arasında değişmektedir (ıslak hazırlama yöntemi ile). Öte yandan çok nokta yöntemiyle belirlenmiş olan likit limit değerleri ile tek nokta yöntemiyle belirlenen değerlerin birbirine yakın olduğu görülmüştür. Sonuç olarak farklı numune hazırlama tekniklerinin üstel katsayı değeri 0.106 ila 0.133 arasında olup, ortalama değer olarak 0.120 elde edilmiş ve 
bu değerlerin ASTMD4318-17 de tavsiye edilen 0.121 değerine yakın olduğu görülmüş ve bu farkl1lıların likit limit değerlerinde ihmal edilebilir bir farklılığa yol açtı̆̆ sonucuna varılmıştır (0-\%2).

Anahtar Kelimeler: Likit limit, Çok nokta, Tek nokta

\section{INTRODUCTION}

The Atterberg limits are index properties of fine grained soils that are used for classification, as well as, for estimating engineering properties of these soils, such as shear strength, compressibility, swelling potential and for evaluating the suitability of them to be used as a fill material or as a subgrade soil (Atterberg, 1911; Casagrande, 1932; Olmstead and Johnson, 1955; Terzaghi et al., 1996; Jefferson and Rogers, 1998; Orhan and Özer, 2006; Zolfaghari et al., 2015; Stanchi et al., 2017). In order to determine Atterberg limits, ASTM D4318-17 requires soil samples to be prepared either by wet preparation, or by dry preparation methods (at room temperature or in an oven at a temperature not exceeding $60^{\circ} \mathrm{C}$ ). This standard method for determining the liquid limit (LL) requires that, at least three trials be made, each at a different moisture content. In the conventional multi-point test, the aim is to obtain the water content of the soil sample that requires 25 blows for the closure of the opening (for a length of $13 \mathrm{~mm}$ ), which is originally created by a groove tool as described by ASTM D4318-17. However, since obtaining 25 blows exactly, is difficult, an interpolation with several data points are done to find the water content at 25 blows. Also, there is another way to determine the LL of a soil sample, which is called "one-point method" (US Waterways, 1949, Olmstead and Johnston, 1955, Eden, 1955, Norman, 1959, Mohen and Goel, 1958, Roje - Bonacci, 2004). This method requires obtaining blow count between 20 and 30 for closure of the opening in Casagrande cup, by a $13 \mathrm{~mm}$ length and determining the water content of the soil sample at that consistency. Then, an equation is to be used to find the LL at 25 blow count. This method is also standardized by ASTM (ASTM D4318-17), as "method B", and by British Standards (BS1377). ASTM D4318-17 suggests an equation and a power coefficient to determine LL of a soil sample corresponding to 25 blow counts, from one data point (equation 1).

$$
L L_{n}=w_{n}\left(\frac{N_{n}}{25}\right)^{0.121}
$$

The power coefficient suggested by ASTM is 0.121 , whereas 0.092 and 0.121 are used by British Standards BS1377 and German DIN18122 standards, respectively.

ASTM D4318-17 notes that one-point method may not be applicable for some soils, such as organic soils, and soils from marine environment. Similarly, according to Eden (1955), the assumptions made in one-point method is not strictly correct for highly organic soils and Eden (1955) stated that "it should not be used on soils which contain an appreciable amount of organic matter". This paper investigates the influences of different sample preparation methods, which are (i) wet preparation, (ii) $60^{\circ} \mathrm{C}$ oven dried preparation, and (iii) $110^{\circ} \mathrm{C}$ oven dried preparation, on power coefficient in equation (1) to determine LL from one point test. The resulting power coefficients are compared with ASTM D4318-17 suggested power value. Furthermore, the differences in liquid limits obtained by multi-point and one-point tests are presented and comparison is provided.

\section{BACKGROUND}

The origin of the one-point method for determination of LL may have developed from the U.S. Waterways Experiment Station (1949) study, which stated that “Dr. Arthur Casagrande suggested that flow 
lines determined by liquid limit tests, plotting both water content and number of blows to a logarithmic scale, might have a constant slope for soils of the same geologic origin". According to Norman (1959) and Mohan and Goel (1960), it is observed in the determination of LL tests that, slopes of the flow curves have nearly the same slope, and this led to an increased interest in one-point method to determine LL of soils.

Some of the benefits of one-point LL test were reported as, a substantial reduction in the time and cost of LL determinations, and reduced work load on technicians (U.S. Waterways Experiment Station 1949, Eden, 1955, Önalp and Kılıç, 1994). Önalp and Kılıç (1994) stated that for big projects with extensive site investigation and laboratory tests, a lot of LL tests are to be done, increasing the work load on technicians, which may increase the tendency of misinterpretation of the tests or mistakes in the long term.

According to Haigh and Vardanega (2014), one-point method is an applicable method to determine LL, and it is allowed in the codes around the world, and hence further examination is valuable. Although it is widely accepted and many codes worldwide allow the usage of the one-point method, limited amount of research is done to investigate the one-point equation for different soils coming from various origins. Önalp and Arel (2013), Olmstead and Johnson (1955), Mohan and Goel (1959) recommended further studies to be conducted to investigate the power coefficient in one-point method for soils of different origins from different parts of the world. On the contrary, some researchers suggest that the geological origin of the soil need not be considered, and that the variation in values of the power ( $\tan$ ๑) for many different soils would be small (Eden, 1955). The power coefficient obtained as a result of various researches are summarized in Table 1. Although the power coefficient seems to very in a broad range (Table 1), the effect of it on LL is not that significant. Olmstead and Johnston (1955) suggested that, if the errors due to the one-point method fall within the \pm 2 percent range in LL, then one-point test should be an acceptable procedure.

Table 1. Power value in one-point LL equation

\begin{tabular}{|c|c|c|c|c|}
\hline Reference & Origin of Soil & $\begin{array}{l}\text { Type of } \\
\text { soils }\end{array}$ & $\begin{array}{c}\text { Number } \\
\text { of } \\
\text { Soils }\end{array}$ & $\begin{array}{c}\text { Average } \\
\tan \beta \text { (range in } \\
\text { parenthesis) }\end{array}$ \\
\hline US Waterways (1949) - & $\begin{array}{c}\text { Southern US (Alluvial Valley of } \\
\text { the Mississippi River, the West } \\
\text { and the East Gulf Coastal } \\
\text { Plains) }\end{array}$ & $\begin{array}{l}\text { medium to highly } \\
\text { plastic inorganic clays, } \\
\text { and a few silts and } \\
\text { sandy clays }\end{array}$ & 767 & $0.121^{*}$ \\
\hline $\begin{array}{l}\text { Olmstead and Johnston } \\
\qquad(1954)\end{array}$ & the US & 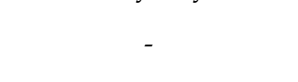 & 759 & 0.135 \\
\hline Eden (1955) & Canadian & - & 484 & $0.108 / 0.100$ \\
\hline Mohan and Goel (1958) & India & $\begin{array}{l}\text { Black cotton soils } \\
\text { (montmorillonitic) }\end{array}$ & 250 & 0.068 \\
\hline Norman (1959) & the UK/Overseas & - & $455 / 49$ & $0.092^{* *}$ \\
\hline $\begin{array}{c}\text { Jain and Patwardhan (1960), } \\
\text { reported by Haigh \& } \\
\text { Vardanega (2014) }\end{array}$ & India & Gangetic alluvium & 32 & 0.085 \\
\hline $\begin{array}{l}\text { Kim (1973), reported by } \\
\text { Haigh \& Vardanega (2014) }\end{array}$ & Korea & Korean soils & 1017 & 0.118 \\
\hline Önalp (1994) & $\begin{array}{c}\text { Eastern Black Sea region, } \\
\text { Turkey }\end{array}$ & Silts \&clays & 332 & 0.112 \\
\hline Vural (1998) & Adapazarı, Turkey & - & 24 & - \\
\hline Roje - Bonacci (2004) & Dalmatian region, Croatia & CH clays & 88 & $\begin{array}{c}0.063 \text { (range: } \\
0.023 \text { to } 0.132 \text { ) }\end{array}$ \\
\hline Uysal (2004) & Adapazarı, Turkey & - & 79 & 0.120 \\
\hline Önalp and Arel (2013) & Istanbul, Turkey & Marine clays & 20 & 0.120 \\
\hline This study & $\begin{array}{c}\text { Northern Turkey (Rize and } \\
\text { Trabzon) }\end{array}$ & $\begin{array}{c}\text { Weathered volcanic } \\
\text { deposits }\end{array}$ & 35 & 0.120 \\
\hline
\end{tabular}




\section{METHODOLOGY}

Soil samples for this study are taken from Northern Turkey, from the cities of Rize and Trabzon, 31 soil samples are taken from eight different sites in Rize and 4 soil samples are taken from one site in Trabzon. The sites in Rize are located in the following villages: Beydere (site 1), Çağlayan/Arslandere (site 2), Köprübaşı (site 3), Aktaş (site 4), Çaglayan (site 5), Merdivenli (site 6), Gündoğan (site 7), Beyazkaya (site 8), and site in Trabzon is located in Ambarlı village (site 9) (Figure 1). Depth of soil samples ranges from $0.2 \mathrm{~m}$ to $4.0 \mathrm{~m}$. When the soil samples were taken at these sites, sample were placed in plastic bags in order to preserve their in-situ water content.

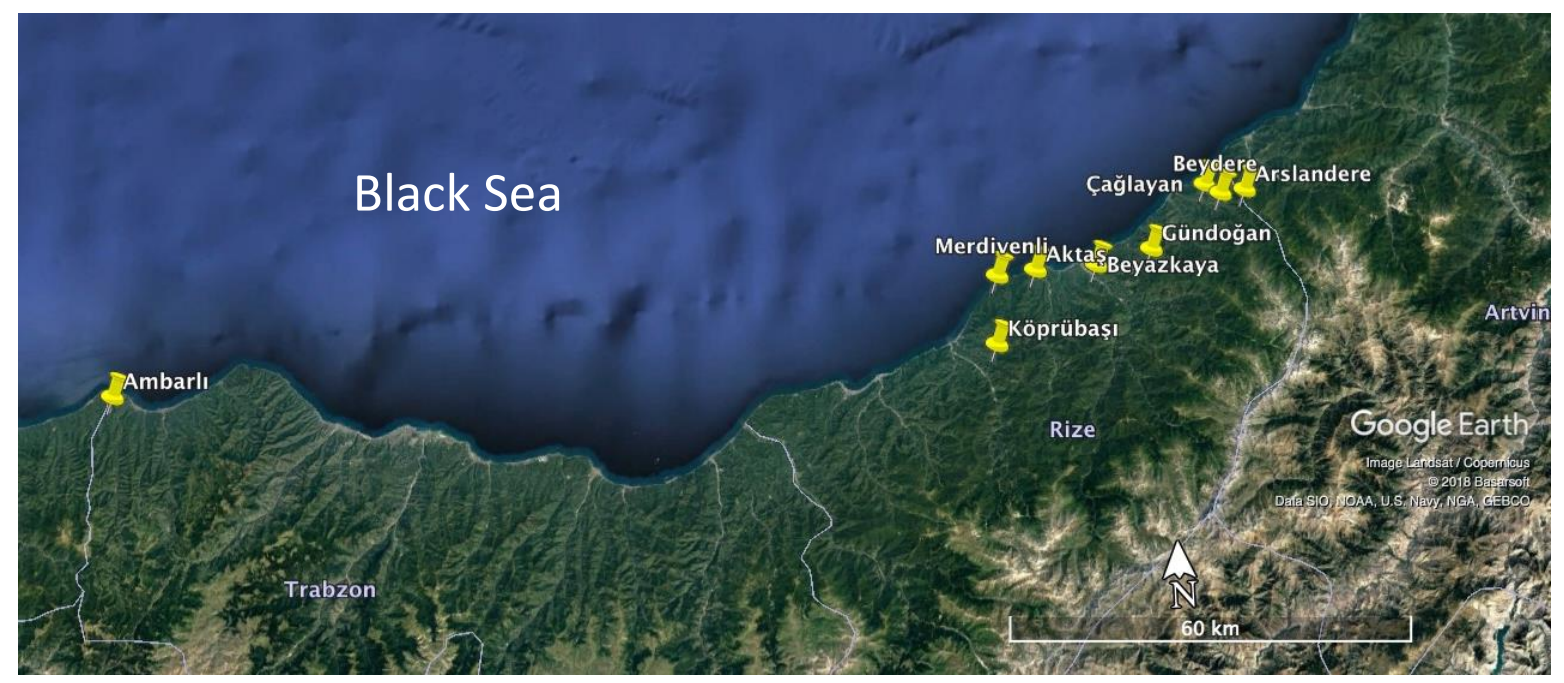

Figure 1. Location of the sites in cities of Trabzon and Rize, Turkey

To conduct the LL tests, three different sample preparation methods are utilized. In wet sample preparation, distilled water is added to the soil in its in-situ water content (without any drying), then the soil is sieved through ASTM No.40 sieve in a wet state. The other sample preparation methods involve oven drying prior to testing. In these methods, the samples are dried in oven at $60^{\circ} \mathrm{C}$ or $110^{\circ} \mathrm{C}$ then pulverized to pass the samples through ASTM No.40 sieve. After addition of distilled water, all samples are allowed to hydrate in the humidity room and tests are conducted according to ASTM D4318-17 using Casagrande cup method. All LL tests are done from wet to dry condition (i.e. from low to high blow count), by mixing and allowing the soil to gradually dry in room temperature.

The effects of drying on liquid limit of soils have been discussed in the literature (e.g. Terzaghi et al., 1996; Jefferson and Rogers, 1998). Kanit et al. (2006) carried out cone penetration-type LL tests on 10 different soil samples and concluded that the samples that are prepared by wet method gave higher LL values (by $1 \%$ to $15 \%$ higher) as compared to other sample preparation methods that involved drying. Wet preparation method is reported to take longer time and it requires more care, therefore it is reported that, in practice, oven drying at $60^{\circ} \mathrm{C}$ or $110^{\circ} \mathrm{C}$ is preferred in most laboratories in Turkey (Kanit et al., 2006; Ozer 2008).

Soil samples that are used in this study are classified according to Unified Soil Classification System, USCS, using ASTM D2487-11. The resulting USCS classification is illustrated in Figure 2. All of the samples are in the ML-OL or MH-OH zone in plasticity chart (Figure 2), having LL of 33\% to 78\% when prepared by drying at $110^{\circ} \mathrm{C}$ and $35 \%$ to $103 \%$ when prepared from in-situ moisture content. ASTM D2487-11 categorizes soils as "organic" if $L L_{110^{\circ}} / L L_{\text {Moist }}$ ratio is less than 0.75 . For soil samples used in this study, this ratio can be 
obtained from the LL values given in Table 2, and soils can be named accordingly, only a few of the soils would be classified as "organic", according to USCS.

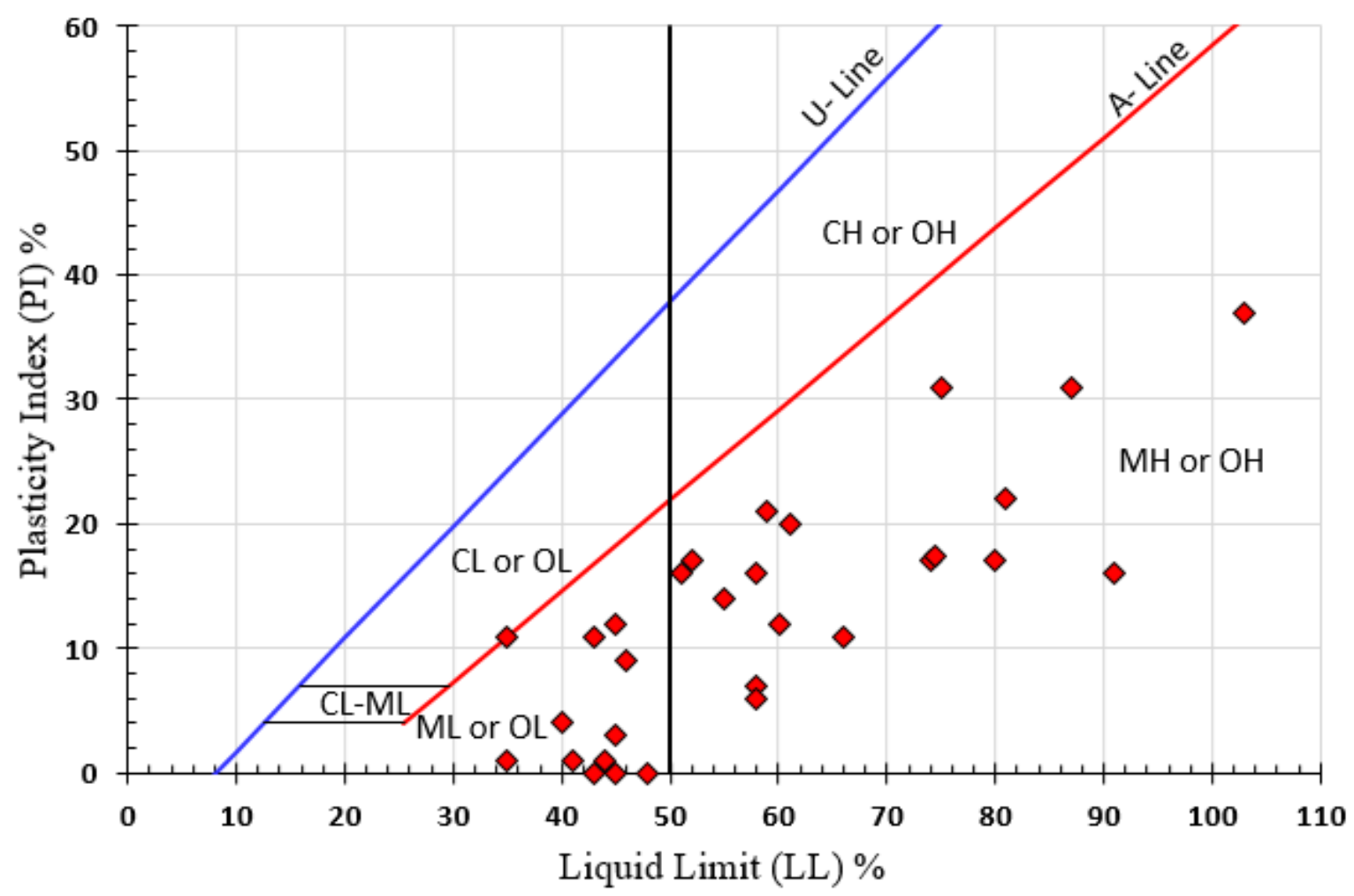

Figure 2. Soil samples in the Plasticity Chart (wet preparation method)

Figures 3, 4 and 5 show the flow curves (water content versus number of drops, or blow counts) in semilogarithmic plot, for samples that are prepared by different sample preparation methods. It is noticeable that in all three figures the slopes of flow curves seem similar, even for different sample preparation techniques. It can be seen that the number of blows versus water content plot changes gradually rather than rapidly, and as stated by US Waterways (1949), Eden (1955), Norman (1959), Mohan and Goel (1960), the slopes of flow curves are similar for these soils. 


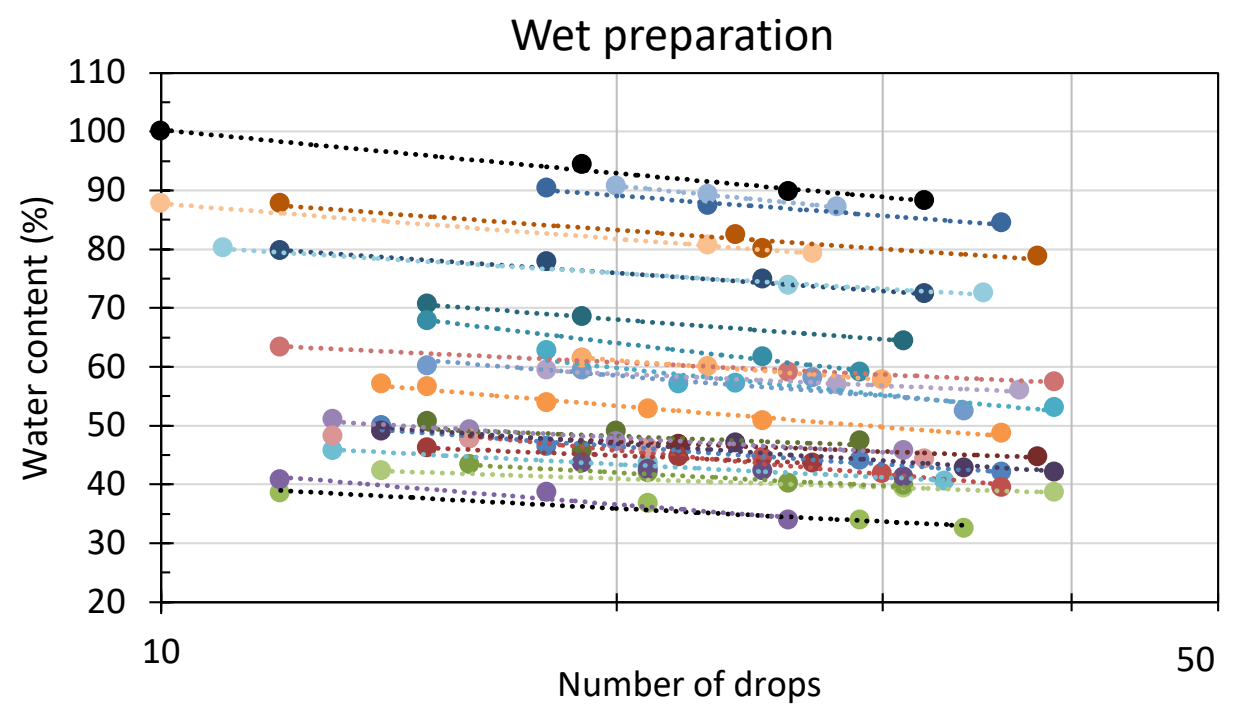

Figure 3. Flow curves for LL determination for samples prepared by wet method

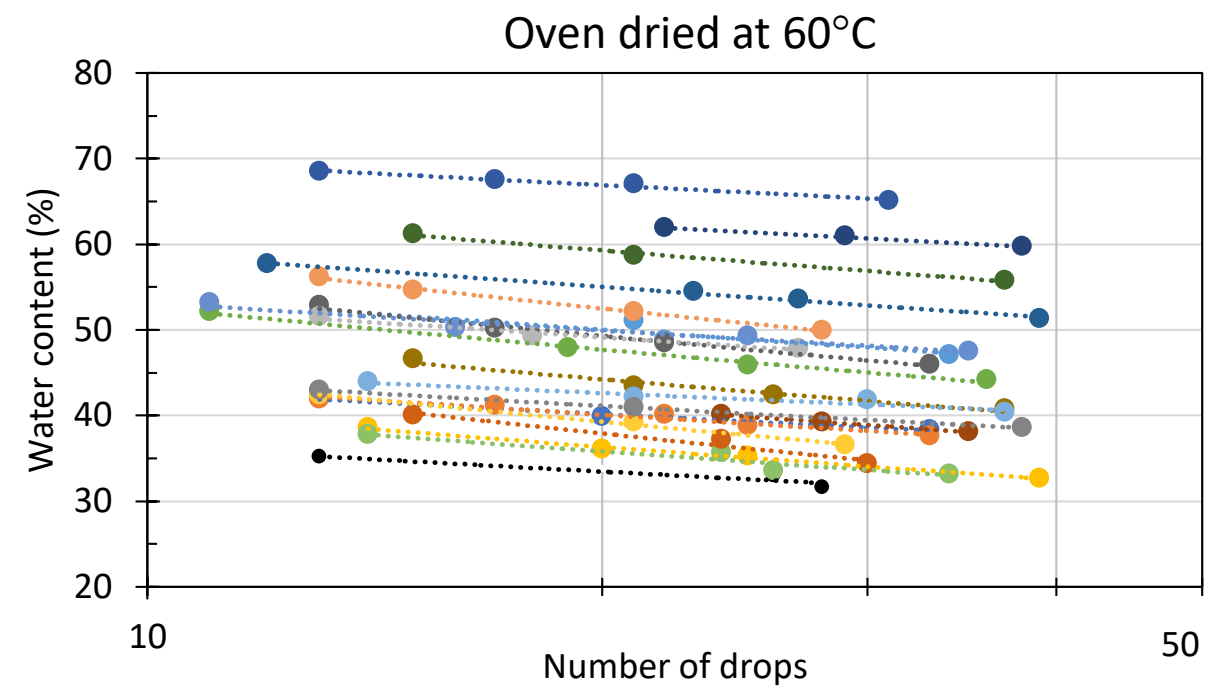

Figure 4. Flow curves for LL determination for samples prepared by oven drying at $60^{\circ} \mathrm{C}$ 


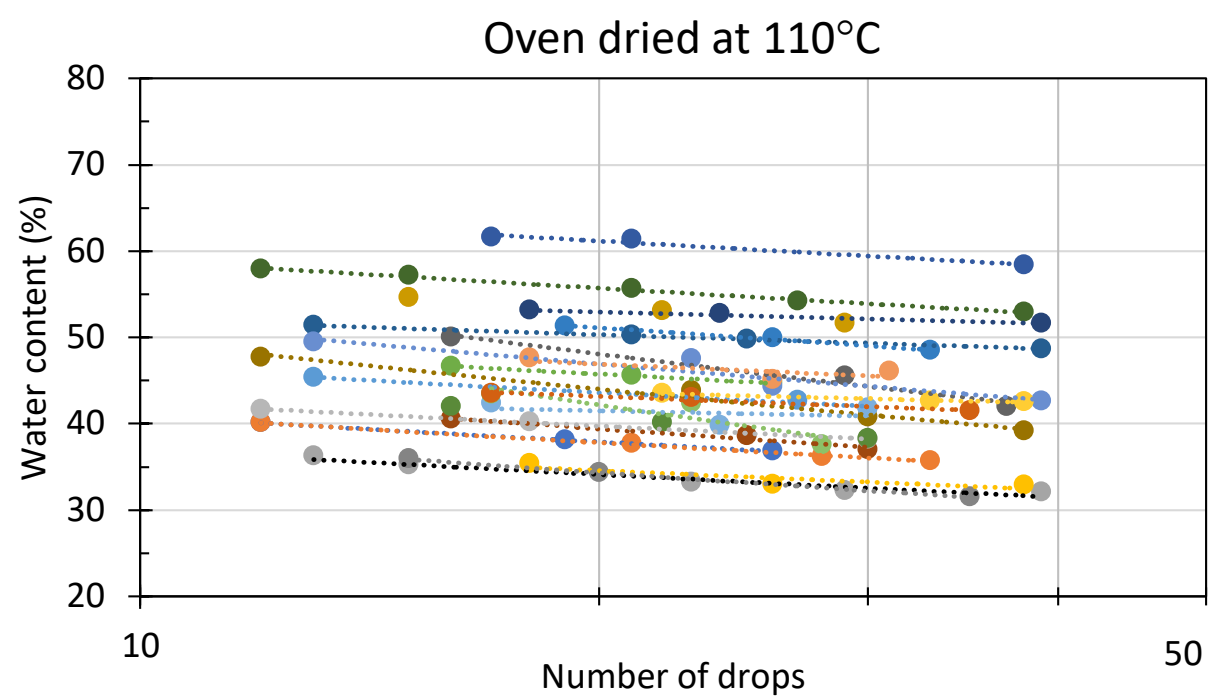

Figure 5. Flow curves for LL determination for samples prepared by oven drying at $110^{\circ} \mathrm{C}$

By using 77 flow curves that are presented in Figures 3, 4 and 5, the power coefficient $(\tan \beta)$ in Equation (1) is calculated for each test. The average $\tan \beta$ values are calculated for three different sample preparation techniques and are presented in Table 2. Table 2 shows clearly that, upon increase in drying temperature $\tan \beta$ values are getting smaller. The frequency distribution of all $\tan \beta$ values from all 77 tests is shown in Figure 6. The average value of $\tan \beta$ from all 77 tests is 0.120 (with a standard deviation is 0.047 ). This power coefficient is in agreement with the ASTM 4318-17 suggested value of 0.121.

Table 2. The average power coefficient, i.e. $\tan \beta$ values in Equation (1), for different sample preparation techniques

\begin{tabular}{|c|cccc|}
\hline & Wet sample preparation & Dried at $\mathbf{6 0 ^ { \circ }}$ & Dried at $\mathbf{1 1 0 ^ { \circ }}$ & Average of all data \\
\hline $\tan \beta$ & 0.133 & 0.120 & 0.106 & 0.120 \\
\hline
\end{tabular}

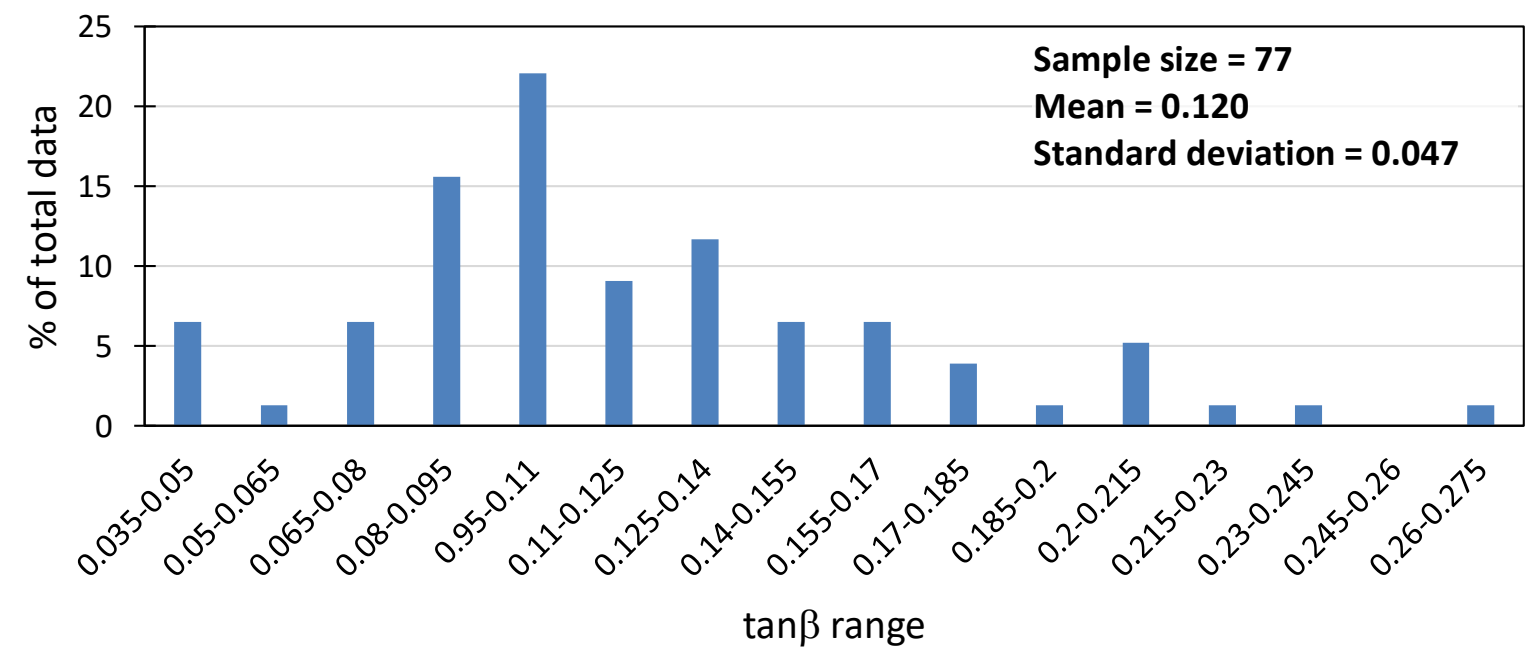

Figure 6. The frequency distribution of $\tan \beta$ values in 77 LL tests 
Having obtained the average $\tan \beta$ values for wet, $60^{\circ} \mathrm{C}$ and $110^{\circ} \mathrm{C}$ oven dried sample preparation methods and the average $\tan \beta$ value of all the samples, an analysis is made to compare the results of LL values calculated using these $\tan \beta$ values and using ASTM D4318-17 suggested $\tan \beta$ value. In the analyses, LL of all the samples are calculated by using (i) ASTM suggested $\tan \beta$ value of 0.121 , (ii) average $\tan \beta$ value of 0.120 which is the average obtained from all three different sample preparation techniques, (iii) average $\tan \beta$ value determined only from the related sample preparation technique (Table 3).

Table 3. Liquid limit (\%) values obtained by multi-point and one-point methods

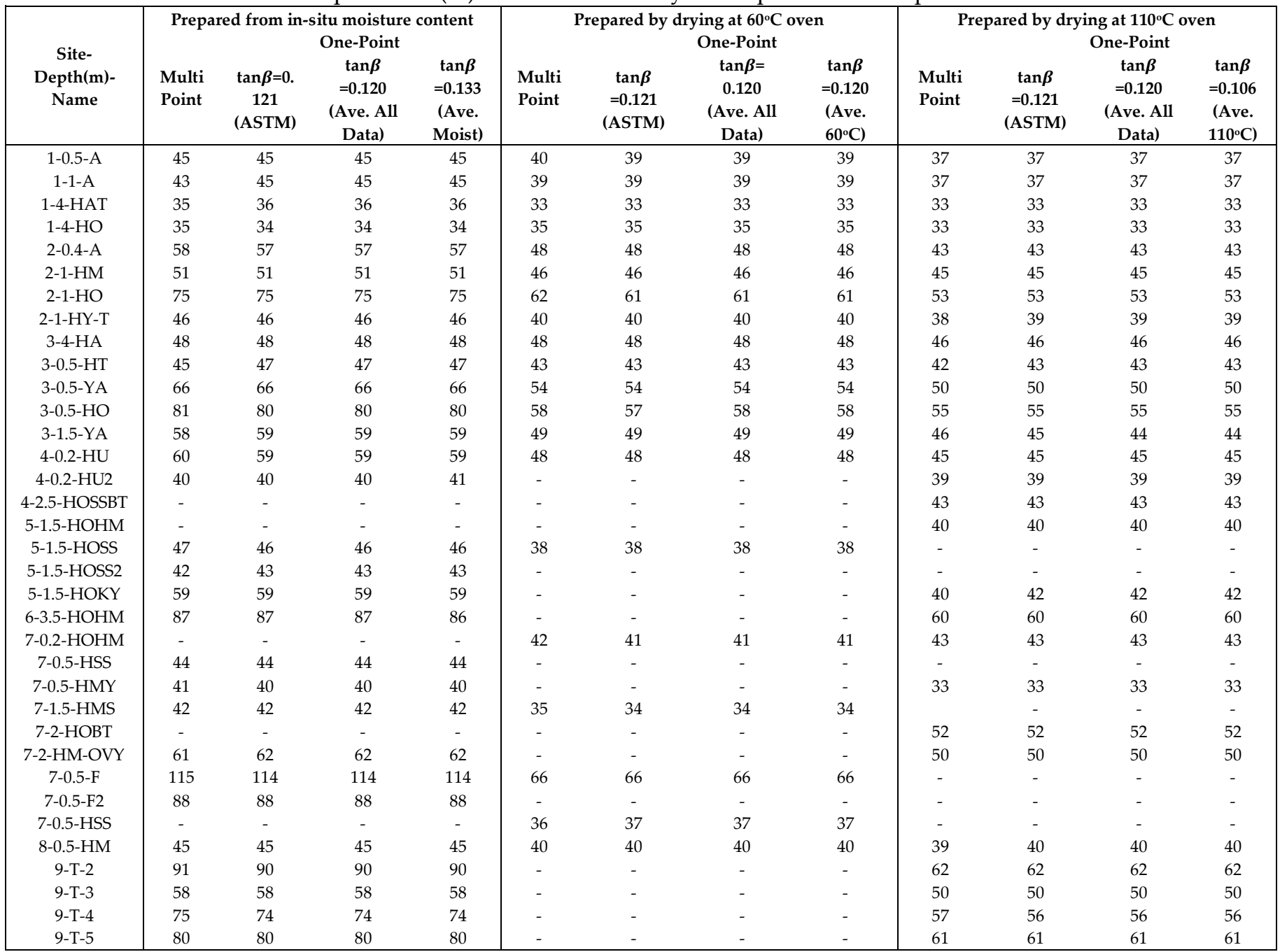


Table 3 clearly shows that for the investigated soils, the LL values, when calculated by using different $\tan \beta$ values differ from each other by $2 \%$ maximum. Furthermore, the comparison of LL obtained by multi-point method and that obtained by one-point method gives the same or very close LL value (Table 3 and Figure 7). In Figure 7, the LL determined from multi-point method versus LL determined from one-point method (using average $\tan \beta$ value of all samples) are compared graphically by plotting them with respect to the $45^{\circ}$ line, and with upper and lower $2 \%$ difference boundaries. According to Eden (1960), different operators were found to give slightly different results when determining the LL of soils. Moreover, Olmstead and Johnston (1954) concluded that, based on many tests by experienced operators and/or different laboratories, the LL of a sample can be determined within $\pm 2 \%$ range. Hence, it can be concluded from Olmstead and Johnston (1954) that if one-point method provides the accuracy of $\pm 2 \%$ difference with respect to multipoint test, the usage of one-point method is justified.

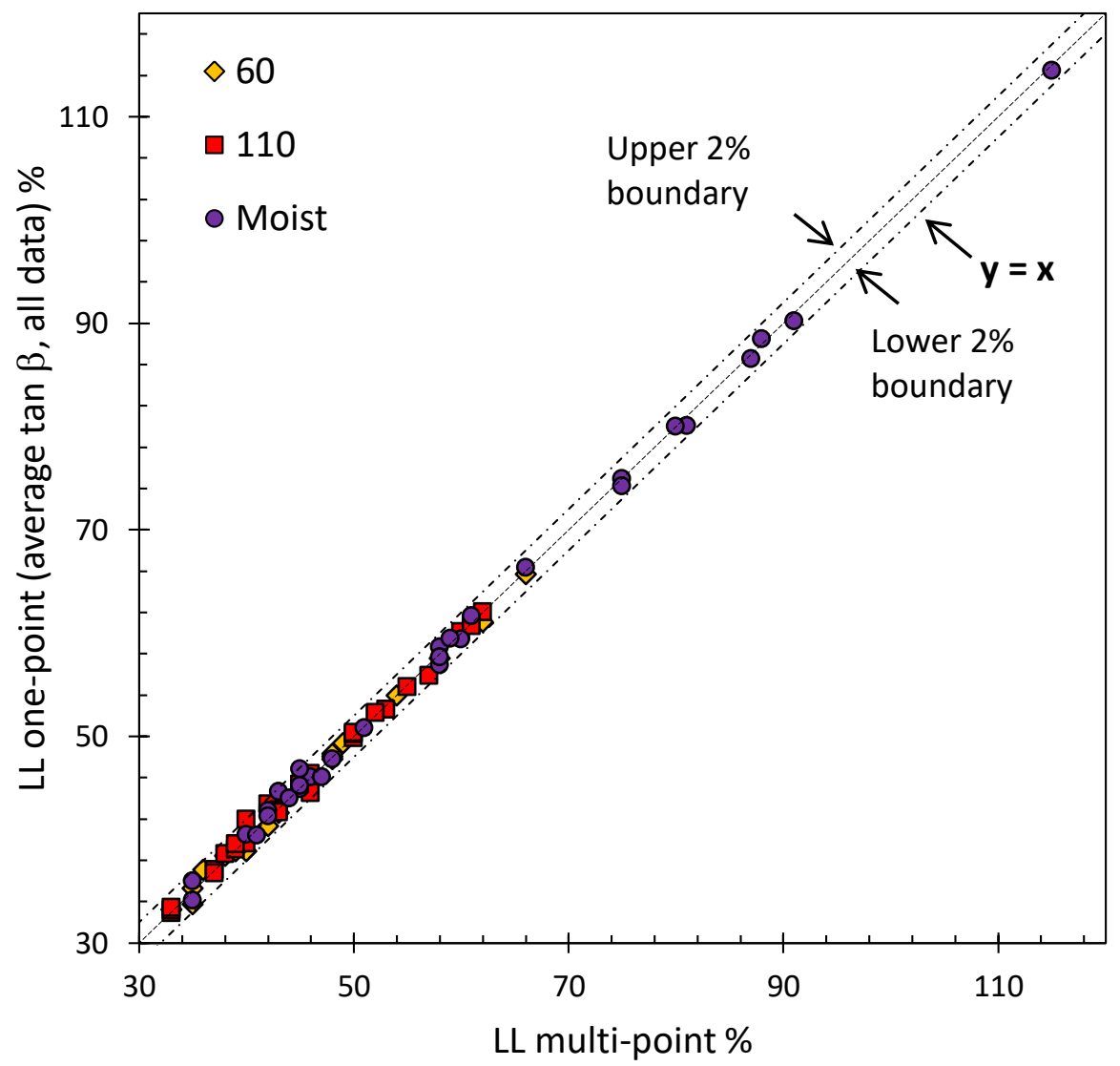

Figure 7. Comparison of LL obtained by multi-point method and one-point methods

\section{CONCLUDING REMARKS}

The power coefficient $(\tan \beta)$ in one-point liquid limit test is determined for various sample preparation techniques and is presented for 35 natural soils from nine sites in Trabzon and Rize, Northern Turkey.

- The power coefficient $(\tan \beta)$ values for 77 Atterberg limit tests using different sample preparation methods have an average value of 0.120 , with a standard deviation of 0.047 . 
- $\quad$ ASTM D4318-17 suggested power coefficient $(\tan \beta)$ value of 0.121 can be used. It can be noted that this power value is demonstrated to give good results for ML-OL and $\mathrm{MH}-\mathrm{OH}$ soils used in this study.

- It is noted that upon increase in drying temperature, $\tan \beta$ values are getting smaller.

- Differences between the LL values obtained by one-point method and multi-point methods are insignificant (i.e. less than or equal to $2 \%$ ), therefore one-point method can be considered as an alternative to multi-point test considering the benefits it provides.

- Determined $\tan \beta$ values in this study and previous studies of different researchers can be considered to be similar.

- As a general recommendation, it is observed during the tests and the data analysis process that, as also stated by Eden (1955), when using one-point method, using a blow count value near 25 increases the accuracy of the predicted LL.

- The results of this research support the conclusion given by the US Waterways (1949) and Eden (1955) that the average slope value appears to be independent of soil type and geologic origin.

\section{ACKNOWLEDGEMENTS}

The authors acknowledge the help provided by Mustafa Hüseyinpaşaoğlu from Turkish National Disaster Agency (AFAD)'s Rize office, Ozan Dadasbilge from GEOCON Company, undergraduate students Berkutay Binol and Isam Khasib for their help during site visits and taking soil sample from the sites.

\section{REFERENCES}

ASTM D2487-11, Standard Practice for Classification of Soils for Engineering Purposes (unified soil classification system), ASTM International.

ASTM D4318-10, Standard Test Methods for Liquid Limit, Plastic Limit, and Plasticity Index of Soils, ASTM International.

Atterberg, A., 1911, “Uber die physikalische bodenuntei suchung and uber die plastizitat der tone int. mitt far bodenkunde", Berlin, 1.

Casagrande, A., 1932, "Research on the Atterberg Limits of Soils", Public Roads, Vol.13, pp.121-136

DIN 18121 Teil 1, Teil 2, Wassergehalt,

DIN 18122 Teil 1, Teil 2, Zustandsgrenzen (Konsistenzgrenzen),

Eden, W. J., 1955, "Trial of One-Point Liquid Limit Method", Proceedings of Ninth Canadian Soil Mechanics Conference, Ottawa, December 15th to 16th 1955 (National Research Council for Canada), Appendix A. Eden, W. 1960. Use of a one-point liquid limit procedure. In Papers on Soils 1959 Meetings. ASTM International.

Haigh, S. K., Vardanega, P. J., 2014, "Fundamental Basis of Single-point Liquid Limit Measurement Approaches", Applied Clay Science, Vol. 102, pp. 8-14

Jain, L.C., Patwardhan, N.K., 1960, "Physical Properties of Soils from the Ganges Valley", Journal of Scientific and Industrial Research (India), Vol. 19A(4), pp. 162-167.

Jefferson, I., Rogers, C. D. F., 1998, "Liquid Limit and the Temperature Sensitivity of Clays", Engineering Geology, Vol. 49(2), pp. 95-109.

Kanit, R., Özer, M., Özdemir, Ş., 2006, “Effect of Sample Preparation Method on the Cone Penetration Liquid Limit Value (Örnek Hazırlama Yönteminin Koni Batma Likit Limit Değerine Etkisi)", Journal of Selcuk-Technic, Volume 5, Number: 3-2006.

Kim, J. B., 1973, "A study on the General and One Point Method of Test for Liquid Limit Procedure", Journal of the Korean Society of Agricultural Engineers, Vol. 15(4), pp. 3153-3159. 
Mohan, D., Goel, R. K., 1958, "Rapid Methods of Determining Liquid Limit of Soils", Journal of Scientific and Industrial Research (India) A 17, pp.498-501

Norman, L.E. J., 1959, "The One-Point Method of Determining the value of the Liquid Limit of a Soil", Geotechnique, Vol. 9 (1), pp.1-8

Olmstead, F. R., Johnston, C. M., 1955, “Rapid Methods for Determining Liquid Limits of Soils”, Highway Research Board Bulletin, (95).

Orhan, M., Özer, M. 2006, “Comparison of Casagrande and Cone Penetration Methods in Determination of Liqid Limit of Natural Soils", Gazi Üniversitesi Mühendislik-Mimarlık Fakültesi Dergisi, Vol. 21(4).

Önalp, A., Kılıç, C., 1994, “One Point Method for Liquid Limit of Clays of Eastern Black Sea”, Proceedings of the 5th National Soil Mechanics and Foundation Engineering Conference, Ankara, 155-160. (in Turkish)

Önalp, A., Arel, E., 2013, “Determination of Liquid Limit of Clays from European Section of İstanbul (Likit limitin tek nokta yöntemi ile ölçümü ve İstanbul killerinde uygulama)", 5. Geoteknik Sempozyumu, 57 Aralık 2013, Çukurova Üniversitesi, Adana (in Turkish).

Özer, M., 2008, "Effects of Sample Preparation on the Liquid Limit Determined by Cone Penetration Test", Journal of Faculty of Engineering, Architecture, Gazi University, Vol. 23, (3), pp.689-698.

Roje-Bonacci, T., 2004, "Liquid Limit Determination of the High Plastic Clays by One-Point Method", 4th Slovenian Geotechnical Congress and 5th Sukljetovi days, p. 199-204.

Stanchi, S., Catoni, M., D'Amico, M. E., Falsone, G., Bonifacio, E., 2017, “Liquid and Plastic Limits of Clayey, Organic C-rich Mountain Soils: Role of Organic Matter and Mineralogy", Catena, Vol. 151, pp.238246.

Terzaghi, K., Peck, R. B., Mesri, G., 1996, Soil Mechanics In Engineering Practice, John Wiley \& Sons.

US Waterways, 1949, Simplification of the Liquid Limit Test Procedure, U.S. Army Corps of Engineers Waterways Experiment Station, Technical Memorandum No. 3-286, 64 p.

Uysal, A., 2004, Adapazarı ve Civarında Likit Limit Deneyinde Kullanılacak $\beta$ Katsayısının Bulunması, Yüksek Lisans Tezi, Sakarya Üniversitesi.

Zolfaghari, Z., Mosaddeghi, M. R., Ayoubi, S., Kelishadi, H., 2015, "Soil Atterberg Limits and Consistency Indices as Influenced by Land use and Slope Position in Western Iran", Journal of Mountain Science, Vol. 12(6), pp. 1471-1483. 